\title{
Diabetes a kardiovaskulární onemocnění
}

V současné době zaměstnává pozornost odborné i laické veřejnosti zejména celosvětový výskyt koronavirové infekce. Obavy vzbuzuje nejen rychle narůstající počet nakažených, ale také smrtnost, která je poměrně vysoká u jedinců vyšších věkových kategorií. Bezesporu se jedná o závažný zdravotní, ale také socioekonomický problém. Nevíme, do jaké míry nás zasáhne a kdy tato epidemie skončí. Přesto je zřejmé, že nadále existuje řada důvodů se více obávat stávající pandemie diabetu, a to zejména z dlouhodobého hlediska. Aktuálně je celosvětová prevalence diabetu odhadovaná na 463000000 lidí a ročně na diabetes zemře asi 4200000 nemocných (1). Předpokládá se, že do roku 2045 bude na světě asi 700000000 diabetiků a je tedy pravděpodobné, že diabetes, respektive jeho komplikace budou jednou z nejčastějších príčin úmrtí.

Na vysoké morbiditě i mortalitě pacientů s diabetem se podílí zejména kardiovaskulární onemocnění. Diabetici mají asi 2 krát vyšší riziko ischemické choroby srdeční, cévní mozkové př́hody i úmrtí z kardiovaskulárních příčin a 2-5 krát vyšší riziko vývoje srdečního selhání (2). V roce 2018 vznikla nová doporučení EASD/ADA pro léčbu diabetu 2. typu, která v terapeutickém algoritmu kladou otázku př́tomnosti kardiovaskulárních onemocnění na přední místo (3). Máme totiž k dispozici antidiabetika, která z tohoto pohledu mohou osud diabetiků významně ovlivnit. Pozitivní roli některých agonistů receptorů pro GLP-1 (glucagon like peptide-1) a gliflozinů v redukci kardiovaskulárních chorob zdưrazňují při výběru antidiabetické léčby také nová doporučení ESC z roku 2019 (2). O tom, že v diabetologii se stále něco děje, svědčí i aktuální update již zmíněných EASD/ADA doporučení (4). Ten vyšel za pouhý rok po jejich zveřejnění a mimo jiné rozšiřuje okruh nemocných profitujících ze zmíněných kardiovaskulárně protektivních léků o vysoce rizikovou populaci diabetiků v primární prevenci.

Této problematice a řadě dalším poznatkưm se věnuji stěžejní články aktuálního čísla Vnitřního lékařství. Inkretinová léčba, která zahrnuje prístup založený na zvýšení endogenních hladin GLP-1 pomocí gliptinů nebo na podávání GLP-1 agonistů, představuje moderní trend v léčbě diabetu spojený s minimem nežádoucích účinků. Profesor Haluzík se ve svém přehledném sdělení zaměřil na její kardiovaskulární působení. Poukazuje na rozdíly mezi gliptiny a GLP-1 agonisty, včetně rưzného ovlivnění kardiovaskulárního rizika, z čehož vyplývá jejich současné místo v terapeutickém algoritmu diabetu 2. typu. Docent Prázný se zamýšlí nad aktuálním postavením další skupiny moderních antidiabetik - gliflozinů nejen z pohledu diabetologa, ale i kardiologa a nefrologa. Revoluční prínos této léčby u nemocných se srdečním selháním a chronickým onemocněním ledvin je doložen bez ohledu na glykemickou kompenzaci a ž̌ejmě brzy nastane doba, kdy se začne využívat i u nediabetiků. Profesor Svačina popisuje roli metabolických komorbidit obezity na rozvoji kardiovaskulárních chorob včetně možností jejich terapeutického ovlivnění. I zde se mohou uplatnit glifloziny a agonisté GLP-1 receptorů. Také některá další sdělení tohoto číla jsou věnována problematice diabetu, jeho komplikacím i léčbě, a to včetně terapie diabetu během hospitalizace. Ve zkratce se dozvíme, co přináší internistům nová ESC doporučení pro léčbu diabetu, a především pro mladé lékaře je určena diferenciální diagnostika hypoglykemických stavů. Nezapomeňte si prohlédnout i články publikované v e-verzi časopisu, řada z nich se věnuje problematice metabolických a endokrinních poruch.

Žijeme ve velmi dynamické době, která přináší určité nejistoty a nepředvídatelné události. Kdo by si před půl rokem představil, že budeme čelit epidemii koronavirové infekce. Přestože počet úmrtí v souvislosti s ní roste ve světě každým dnem, pořád je o tři ráády nižší ve srovnání s roční úmrtností na komplikace diabetu. V mnoha oblastech i nadále narůstá výskyt nových prípadů, ale objevují se také príznivé zprávy a v původních ohniscích infekce počet nakažených začíná pomalu klesat. A tak všichni doufáme, že s nástupem jarních měsíců se i v Evropě situace podstatně zlepší. Nezbývá, než si prát, aby se tato epidemie stala minulostí, abychom se bez obav mohli nejen setkávat na našich odborných akcích, ale abychom se nadále mohli plně věnovat naší každodenní práci včetně péče o nemocné s diabetem.

doc. MUDr. David Karásek, Ph.D.

III. interníklinika - nefrologická, revmatologická a endokrinologická,

LFUPa FN Olomouc

\section{LITERATURA}

1. Saeedi P, Petersohn I, Salpea P, et al. IDF Diabetes Atlas Committee. Global and regional diabetes prevalence estimates for 2019 and projections for 2030 and 2045 : Results from the International Diabetes Federation Diabetes Atlas, 9(th) edition. Diabetes Res Clin Pract 2019; 157: 107-843.

2. Cosentino F, Grant PJ, Aboyans V, et al. ESC Scientific Document Group. 2019 ESC Guidelines on diabetes, pre-diabetes, and cardiovascular diseases developed in collaboration with the EASD. Eur Heart J 2020; 41: 255-323.

3. Davies MJ, D'Alessio DA, Fradkin J, et al.Management of Hyperglycemia in Type 2 Diabetes, 2018. A Consensus Report by the American Diabetes Association (ADA) and the European Association for the Study of Diabetes (EASD). Diabetes Care 2018; 41: 2669-2701.

4. Buse JB, Wexler DJ, Tsapas A, et al. 2019 Update to: Management of Hyperglycemia in Type 2 Diabetes, 2018. A Consensus Report by the American Diabetes Association (ADA) and the European Association for the Study of Diabetes (EASD). Diabetes Care 2020; 43: 487-493. 